\title{
Fra Tyrstrups herreds rettersted 1700.
}

\section{Af Johan Hvidtfeldt.}

Retsusikkerheden var i fortiden forholdsvis stor paa grund af den ringe udvikling, politivæsnet havde. Straffene skulde derfor $\mathrm{i}$ højere grad end nu virke afskrækkende og var følgelig meget haarde, efter nutidens opfattelse ofte grusomme og meningsløse. Selv smaa forseelser maatte sones med døden - som regel hængning.

Alligevel kendes der kun forholdsvis faa henrettelser i Nordslesvig, og vi ved ret lidt om, hvordan det i enkeltheder gik til, naar misdæderen maatte lade livet for hoddelens haand. Den følgende optegnelse, der er hentet fra Tyrstrup og Hjerndrup kirkebog, fortæller lidt derom og giver ogsaa nærmere oplysning om, hvor herredets tingsted fandtes i aaret $\left.1700^{1}\right)$.

Ved Straarup nævnes en tinghøj, men da dette navn ikke er overleveret i de æaldre kilder ${ }^{2}$ ), er det maaske en nyere "poetisk« betegnelse. I saa tilfalde maa Tyrstrup herreds forste kendte tingsted siges at have været paa "Tingskovhede" paa Aastorp mark (Taps sogn), hvilket sted endnu i 1780 betegnedes ved en stensatning. I 1512 tog hertug Hans den rldre »de gamle tingstokke fra deres tidligere sted og satte dem ved Aller kirke som det bekvemmeste sted for undersaatterne i Tyrstrup herred og for fremmede med hensyn til postgangenl, fordi Aller laa ved den almindelige hærvej«. Flytningen blev flere gange bekræftet af de danske konger og senere blev der her bygget et tinghus ${ }^{3}$ ).

Stednavnet Tinghusmark fortæller endnu derom, og navllet Galgebjerg (1788: Gallenberg haue) ${ }^{4}$ ), en bakke mellem Aller og Kobbersted, fortæller om retterstedets nojagtige plads, netop

\footnotetext{
1) Se ogsaa Carsten Petersen: Slenvigske Præstel $37 \%$.

2) Sonderjyske Stexlnavne I. $\$$.

3) Vejle Amits Aarhager 192\%. 149 f. $1941 \% 91 \mathrm{f}$.

4) Sonderjyske Stednavne I. 118, 1:1.
} 
det sted, hvor den i optegnelsen nævnte Hans Jensen Bødker maatte lade sit liv.

Anno 1700 den 30. Junij døde Kiersten Hansis i Hjerndrup, som var en Barselquinde, blef bestediget d. 4. Julij, som var Dominica 4. post Trinitatis (4. juli), og satt udi aaben Graff: formedelst der sagdis, at hendis Mand Hans Bödicker skulde hende udi Barsel-Potten, en Forgift hafve tilberedt d. 22. Junij, hvorefter hun heftig: ("salva venia«) $)^{5}$ ): evomerita ${ }^{0}$ ) og dend ganske Nat sig ilde befunden, følgendis den 23 . Junij, blef hun af mig i samme svaghed berettet. Og i hvor vel hun for mig negtede: (der ieg inqvirerede om dette) at hendis Mand hafde tilberedt forgiften: og hun hannem derfor paa det beste undskylte, dissligeste at hun icke hafde at klage og ancke paa Manden, jeg tilspurde og de tilstæde værende Koner af Naboskabet, om de viste noget aff denne sags beskaffenhed, hvilke samptlige svarede neij, paa den 9. dag derefter, som var den 30 . Junij, døde denne Barsel-Kone; Men der Sagen blef ret undersøgt og for Rætten Examineret, blef det Manden icke allecniste ofverbevist; Mens hand og det self for Øfrighedes bekiendte, at hand gierningen disvær bedrefven og giordt hafde, hvor for og Hans Bödicker blef den 3. Aug: for Rætten dømbt fra Lifvet, og blef hand den 17. dito lefvendis stejlet paa Tyrstrup-Herridz-Rattersted mellem Aller og Brabeck.

Den 17. Aug: som var en Tisdag, døde dend Misdædere Hans Jensen Bödicker af Hiendrup en forsmædelig dad; thi hand blef (ofvenfra) lefvendis stejlet:/ paa Tyrstrup Herritz Rættersted mellem Aller og Brabeck paa Kaabersted Mark, hvor Gallien staar, og efter at hand var stejlet, blef Kroppen lagt paa Stejlen, og hofvedet hlef tilnaglet paa Pælen ofver Kroppen paa samme Stejle/: formedelst hand sin Hustru Kiersten Hansis

5) Med forlov.

G) Kasterle op. 
Lafde med forgift ombragt, i hendis Barselsæng, og des foruden ilde taget af sted med hende. Jeg paa Embedets Vegne, betiente hannem, som til forn i fængselet 2de gange med den $\mathrm{H}$ (ellige) Communion, og der ofte, ja 2de gange hver Uge besagte hannem, for at formane, troste og Undervise hannem til Salighed, saa og her til Rætterstedet følgede og beglejdede hannem tillige med min Naboe Hr. Rasmus Christopfersen i Fjelstrup, og gik Synderen mellem os begge: og vi saa begge Vexels-vis med Guds ord, Psalmer og Bønner, dend ganske Veij igiennem, fra Ting-Huse ved Aller, til Rætterstedet, trøstede og undervisede hannem om en god Beredelse til dend forestaaende Død og Lidelse. Vi var med Fangen udi en Qvadrangulo af Herritz Bønderne indsluttede, og omringede, hvilcke med deris Sckarpe og ladte Gevær, fulte og følgede os op til Rætterstedet: hvor denne Synder (der ieg til sist mit Embede med og hos hannem forrættet) forst kom i Bødelens Hænder, og blef ieg hos Synderen saa længe bestandig, til hand ganske var henrettet. Mig blef af Øfrigheden for min hafte Umag med denne Misdæder og Synder tillagt .... 16 Mark lybsk.

Johan Hvidtfeldt. 